\title{
MAŁŻEŃSTWO W PORZĄDKU PRAWNYM KOŚCIOŁÓW PROTESTANCKICH W POLSCE
}

Coraz większa mobilność mieszkańców kontynentu europejskiego w naturalny sposób powoduje m.in. pogłębianie się pluralizmu religijnego, światopoglądowego i kulturowego Polski. Tytułem ilustracji tego faktu podać można informację, na jaką natrafił niedawno autor niniejszych rozważań w przedsionku kościoła ojców pijarów na warszawskich Siekierkach. Na wywieszonej tam tablicy ogłoszeń zamieszczone były tzw. zapowiedzi przedślubne. $\mathrm{Z}$ ich lektury wynikało, że spośród pięciu planowanych w parafii nowych związków małżeńskich, dwa zawierane były z niekatolikami. Jeden ze ślubów jak głosiły zapowiedzi - dotyczył osoby „wyznania anglikańskiego”, drugi „wyznania protestanckiego". Z zebranych w tym kontekście informacji wynika, że przypadków małżeństw mieszanych katolików z wyznawcami protestantyzmu jest w Polsce coraz więcej. Należy sądzić, że ta tendencja będzie się utrzymywać, czy nawet nasilać. Omawiana okoliczność uzasadnia zatem bliższą prezentację norm i praktyk dotyczących małżeństwa, przyjętych w Kościołach protestanckich, co może być pomocne nie tylko dla osób przygotowujących się do zawarcia małżeństwa, ale także dla wspólnot religijnych, do których należą. W warunkach polskich danymi z tego zakresu mogą być zainteresowani zwłaszcza przedstawiciele Kościoła katolickiego, a szczególnie kanoniści katoliccy, którzy - jak pokazuje opisany przypadek ze stołecznych Siekierek - mogą mieć coraz częściej do czynienia $\mathrm{z}$ tą złożoną i słabo opracowaną w naszym kraju problematyką.

Rozważania niniejsze są syntetyczną prezentacją zasadniczych wątków aspektu prawnego małżeństwa w polskich Kościołach protestanckich. Składają się nań uwagi o istocie protestantyzmu i jego aspekcie kościelno-ustrojowym, o założeniach prawa kościelnego w protestanckich związkach wyznaniowych oraz wywód na temat 
kluczowych unormowań dotyczących małżeństwa w porządku prawnym omawianych Kościołów. Całość zamyka zwięzłe podsumowanie.

\section{Protestantyzm - uwagi wprowadzające}

W ramach współczesnego chrześcijaństwa protestantyzm zajmuje ważne miejsce jako trzeci obok katolicyzmu i prawosławia nurt chrystianizmu. Szacuje się, że skupia on co najmniej pół miliarda osób, choć liczba protestantów może być faktycznie znacznie większa. ${ }^{1}$ Od czasu XVI-wiecznej reformacji ukształtowało się kilka podstawowych nurtów protestantyzmu, począwszy od luteranizmu, kalwinizmu (ewangelicyzmu reformowanego) i anglikanizmu, przez baptyzm i metodyzm, po powstały w XX w. pentekostalizm (ruch zielonoświątkowy). ${ }^{2}$ Wymienione środowiska można określić mianem „wyznań” protestanckich, gdyż mają odrębną tożsamość teologiczną, określoną w czasie konstytuowania się zwykle w dokumentach doktrynalnych zwanych np. „konfesjami”. ${ }^{3}$ Poszczególne wyznania protestanckie nie tworzą jednolitych bytów organizacyjnych, składają się z wielu wspólnot (związków wyznaniowych, denominacji) najczęściej o zasięgu krajowym, noszących zwykle nazwę Kościołów i mających partnerskie więzi z innymi Kościołami tego samego wyznania, skupionymi w ogólnoświatowych organizacjach konfesyjnych, które z kolei nie są wszakże postrzegane jako Kościoły.

1 Zob. T. M. J o h n s o n, D. B. B a r r e t t, Statistics, w: H. J. H i 11 e r b r a n d (red.), Encyclopedia of Protestantism, t. 4, Abingdon-New York 2004, s. 344. W publikacji tej liczbę protestantów określono na $833 \mathrm{mln}$.

2 Dyskusyjna jest sprawa zaliczenia anglikanizmu do protestantyzmu, a to ze względu na łączenie w nim elementów właściwych teologii i praktyce protestanckiej i katolickiej; zob. Protestantism, w: E. A. L i v i n g s t o n e, Oxford Concise Dictionary of the Christian Church, Oxford-New York 2000, s. 471. Poza wymienionymi nurtami do protestantyzmu nierzadko zalicza się także adwentyzm; zob. K. K a r s k i, Symbolika. Zarys wiedzy o Kościołach i wspólnotach chrześcijańskich, Warszawa 2003, s. 210.

3 Zob. np. J.H. L e it h (red.), Creeds of the Churches. A Reader in Christian Doctrine from the Bible to the Present, Louisville, Ky 1982, s. 61-398. 
Przykładowo, Kościół Ewangelicko-Augsburski w Rzeczypospolitej Polskiej jest Kościołem luterańskim obejmującym teren państwa polskiego, ${ }^{4}$ dla którego bratnimi Kościołami są np. Luterański (do 2000 r. Państwowy) Kościół Szwecji czy Śląski Kościół Ewangelicki Augsburskiego Wyznania w Republice Czeskiej. ${ }^{5}$ Wspólnie z nimi należy do Światowej Federacji Luterańskiej, która ogółem skupia 140 Kościołów tej konfesji z 78 krajów i ponad $65 \mathrm{mln}$ wiernych. ${ }^{6} \mathrm{Za}$ sprawą tendencji ekumenicznych poważna liczba Kościołów protestanckich zaczęła przekraczać dzielące je bariery, w wyniku czego powstały protestanckie kościelne organizacje międzywyznaniowe (np. na naszym kontynencie zaistniała Wspólnota Kościołów Protestanckich Europy oparta na tzw. Konkordii Leuenberskiej) ${ }^{7}$ a nawet wspólne Kościoły jednoczące wiernych przynależących kiedyś do różnych wyznań wyrosłych z reformacji. Przykładem takiego protestanckiego Kościoła unijnego jest utworzony w 2012 r., z Kościołów prezbiteriańskiego, baptystycznego i metodystycznego, Kościół Ekumeniczny w Szwecji. ${ }^{8}$

Ponieważ protestantyzm nie tworzy jednej organizacji i nie ma jednego ośrodka decyzyjnego, nie istnieje w pełni obiektywny sposób

4 Bez większego znaczenia dla tej charakterystyki jest fakt posiadania przez omawiany Kościół placówek duszpasterskich poza Polską, na terenie gdzie istnieją inne Kościoły luterańskie.

5 J. S z a r e k, J. G r o s s, Struktura oraz życie współczesne Kościoła, w: J. B e1 o w, M. L e g e n d ź(red.), Świadectwo wiary i życia. Kościół Luterański w Polsce wczoraj i dziś, Bielsko-Biała 2004, s. 24.

6 A. K o r c z a g o, Kościót Ewangelicko-Augsburski (Luterański), w: M. P at a lo n, H. Tr a nd a (red.), W drodze za Chrystusem. Kościoły chrześcijańskie w Polsce mówiq o sobie, Kraków 2009, s. 48; K. K a r s k i, Symbolika, s. 148.

7 Te n ż e, Od Edynburga do Porto Alegre. Sto lat dążé ekumenicznych, Warszawa 2007, s. 140-145.

8 T. J. Z i e l i ń s k i, Kościół Ekumeniczny w Szwecji, Jednota 1/2014, s. 20-22. Pomijamy tutaj kwestię innych form zaangażowania ekumenicznego Kościołów protestanckich, które zresztą były prekursorem tej formy zbliżenia chrześcijan. Liczne są bowiem inicjatywy ekumeniczne $\mathrm{z}$ ich udziałem, zwłaszcza w relacjach z Kościołem katolickim i Kościołami prawosławnymi. 
oceniania, która wspólnota chrześcijańska ma charakter protestancki. ${ }^{9}$ Chcąc zatem zakwalifikować dany związek wyznaniowy do protestanckiego kręgu, należy się odwołać się do utrwalonego pojmowania istoty protestantyzmu. Polega ona na uznawaniu dogmatu trynitarnego (istnieje jeden Bóg objawiony w trzech osobach: Ojca i Syna i Ducha Świętego) i chrystologicznego (Jezus Chrystus jest w pełni Bogiem i w pełni człowiekiem), podkreślaniu w porządku źródeł wiary nadrzędnego autorytetu Pisma Świętego (sola Scriptura) i przyjmowaniu, iż zbawienie (usprawiedliwienie) jest dane człowiekowi z samej łaski przez samą wiarę (sola gratia et sola fide). Chrzest udzielany jest z użyciem wody w imię Ojca i Syna i Ducha Świętego, a Eucharystia jako chleb i wino, przy podawaniu kielicha także świeckim. ${ }^{10}$ Pewną formą weryfikacji przynależności danej wspólnoty religijnej do jednego z wyznań protestanckich jest jej członkostwo w którejś ze światowych protestanckich organizacji konfesyjnych, na czele z następującymi: Światowa Federacja Luterańska, Światowa Wspólnota Kościołów Reformowanych, Światowa Konferencja Mennonicka, Światowy Alians Baptystyczny, Światowa Rada Metodystyczna, Światowa Wspólnota Pentekostalna, Międzynarodowa Federacja Wolnych Kościołów Ewangelickich. Poza tymi organizacjami występuje jednak znacząca liczba podmiotów, które niewątpliwie mają charakter protestancki. Czasami mają one nazwy nie przesądzające o ich profilu teologicznym. Dopiero szczegółowe badanie ich założeń doktrynalnych i praktyki religijnej pozwala na stwierdzenie, czy mają cechy uprawniające do zaliczenia ich do protestanckiego kręgu. Kończąc tę skrótową charakterystykę chrześcijaństwa ukształtowanego przez reformację i jej spuściznę, trzeba zaznaczyć, że w poprzek poszczególnych konfesji protestanckich przebiegają granice różnych odmian pobożności, różnych nastawień

9 M.E. M a r t y, Protestantism. Its Churches and Cultures, Rituals and Doctrines, Yesterday and Today, Chicago 1974, s. 78.

10 Zob. J. T. M c N e i 1 1, Protestantism, w: A. R i c h a r d s o n, J. B ow d e n (red.), A New Dictionary of Christian Theology, London 1989, s. 477; Z. P a s e k, Protestantyzm, w: T. G a d a c z, B. M i 1 e r s k i (red.), Religia. Encyklopedia PWN, t. 8, Warszawa 2003, s. 275-279. 
etycznych i różnych szkół teologicznych. Do tego przejawu typowego protestanckiego indywidualizmu przyjdzie nam jeszcze nawiązać, ukazując stosunek Kościołów protestanckich do zagadnień prawnych w ogólności oraz szczegółowych unormowań dotyczących małżeństwa.

\section{Porządek prawny Kościołów protestanckich - zarys charakterystyki}

Stosunek Kościołów protestanckich wobec prawa zdeterminowany został przez założenia reformacji. Do jej haseł należał sprzeciw wobec nadmiernej regulacji życia religijnego przez prawo kanoniczne. Symbolicznym wyrazem tej postawy było spalenie w 1520 r. przez Marcina Lutra księgi przepisów prawa kanonicznego. ${ }^{11}$ Gestu tego nie należy jednak postrzegać jako przejawu antynomizmu. Już pierwsi krzewiciele protestantyzmu dostrzegali bowiem potrzebę normowania życia kościelnego - wiedli jednak spór o to, kto ma mieć władztwo w tym zakresie. W państwach, w których protestantyzm stał się religią urzędow, prawnej regulacji materii kościelnej podjęła się władza świecka. ${ }^{12}$ Natomiast protestanci sprzeciwiający się zwierzchnictwu państwa nad wspólnotą chrześcijańską, najczęściej albo podejmowali próby tworzenia teokracji (państw zdominowanych przez duchowieństwo), ${ }^{13}$ w których wspólnota religijna dyktowała prawo wspólnocie politycznej, albo nadawali swoim Kościołom kształt niewielkich lokalnych stowarzyszeń (gmin), które, unikając powiązań z państwem, określały wewnętrzne normy w drodze porozumień zawieranych między sobą przez ich członków. ${ }^{14}$

11 Zob. J. M. To d d, Reformacja, tłum. J. S. Ł o ś, Warszawa 1974, s. 198.

12 Dotyczyło np. takich krajów jak protestanckie państwa i miasta Rzeszy Niemieckiej, protestanckie kantony Szwajcarii, a także Danii, Szwecji, Norwegii, Anglii, Walii i Szkocja.

13 O takim eksperymencie można mówić przejściowo w przypadku kalwińskiej Szkocji pod rządami Johna Knoxa (1514-1572) oraz niektórych koloniach Nowej Anglii (zwłaszcza Massachusetts). Rozwiązania te miały charakter krótkotrwały i dotyczyły niewielkich organizmów państwowych.

14 W świecie anglosaskim miały one niekiedy kształt „przymierzy” (covenants), „umów” (compacts) lub wyznań wiary (creeds). Dotyczyło to zwłaszcza wspólnot 
W procesie historycznym opisane wyżej dwie skrajne tendencje (oddanie prawa normowania życia kościelnego w gestię państwa oraz zawężenie regulacji do uzgodnień, często nieformalnych, w łonie gminy wyznaniowej) zostały wypośrodkowane. ${ }^{15}$ Przytłaczająca większość Kościołów protestanckich ma znaczące regulacje stanowione przez prawodawcę kościelnego. Największą powściągliwość wykazują obecnie wspólnoty chrześcijańskie zaliczane do tzw. protestantyzmu ewangelikalnego, który genetycznie wywodzi się ze sprzeciwu wobec urzędowych i formalnych Kościołów ukształtowanych w okresie reformacji i reprezentuje tzw. duchowość przebudzeniową. ${ }^{16}$

Naczelne znamiona protestanckiego prawa kościelnego można przedstawić następująco:

- prawo to powstaje zwykle w toku demokratycznych procedur, które teologicznie uzasadnia się m.in. nauką o powszechnym kapłaństwie wszystkich chrześcijan (współodpowiedzialność za Kościół zarówno duchownych, jak i świeckich);

- technika legislacyjna wzorowana jest zwykle na prawie świeckim obowiązującym w państwie, na terenie którego działa odnośny Kościół;

- zakres regulacji zwykle się minimalizuje, by zostawić możliwie dużo miejsca rozstrzygnięciom sumienia wiernych;

- kompetencję stanowienia szczegółowych norm przyznaje się nierzadko także lokalnym gminom (parafiom, zborom);

- dużą rolę odgrywają normy zwyczajowe.

wywodzących się z angielskiego purytanizmu, jak m.in. kongregacjonaliści czy baptyści. Wspomniane przymierza znane były także protestantom anglosaskim próbującym budować wzmiankowane wcześniej amerykańskie teokracje.

15 Istniały jednak wyjątki od tej zasady. Do dzisiaj pewne istotne aspekty działalności Kościoła Anglii reguluje ustawodawstwo państwowe, zaś niemało jest wspólnot protestanckich zwanych ,wolnymi Kościołami”, gdzie brak jest podstawowych formalnych regulacji prawnych. W sprawie Kościoła Anglii zob. T.J. Z i e 1 i ń s k i, Elementy bilateralizmu w brytyjskim modelu stosunków państwo-Kościót, w: M. B i e 1 e c k i (red.), Bilateralizm w stosunkach państwowo-kościelnych, Lublin 2011, s. 333-347.

16 Zob. monograficzne ujęcie tego zjawiska: T. J. Z i e 1 i ń s k i, Protestantyzm ewangelikalny. Studium specyfiki religijnej, Katowice $2014^{2}$, passim. 
Ze względu na zróżnicowaną morfologię norm obowiązujących w omawianych wspólnotach, w tym na przyznanie znaczącej roli normom zwyczajowym, w celu zaznaczenia chęci objęcia niniejszym studium ogółu norm dotyczących małżeństwa, w tytule artykułu uży to określenia „porządek prawny Kościołów”.

Zamykając rozważania wprowadzające, należy zaznaczyć, że w dalszym wywodzie ukazane zostaną normy z zakresu prawa małżeńskiego przyjęte tylko w wybranych, choć reprezentatywnych Kościołach protestanckich istniejących we współczesnej Polsce. Ilekroć dalej będzie mowa o „Kościołach” bez bliższego określenia, należy pod tym pojęciem rozumieć Kościoły omawianej tradycji wewnątrzchrześcijańskiej.

\section{Małżeństwo w polskich Kościołach protestanckich}

\section{Źródła norm o małżeństwie}

Obowiązujące w okresie Polski Ludowej przepisy prawa świeckiego, zakazujące sprawowania ślubów kościelnych przed zawarciem małżeństwa określonego w ustawodawstwie państwowym, stawiało wspólnoty religijne przed koniecznością akceptowania pojęcia małżeństwa przyjętego w Kodeksie rodzinnym i opiekuńczym oraz w aktach go poprzedzających. ${ }^{17}$ Oczywiście Kościoły stawiały kandydatom do kościelnego związku małżeńskiego dodatkowe wymagania o charakterze konfesyjnym, lecz nie podważały one istoty pojęcia występującego w regulacji państwowej. Tym w szczególności można tłumaczyć szczątkowość polskich protestanckich unormowań kościelnych w materii małżeńskiej, w tym i dotyczących pojęcia małżeństwa. Sytuacja zmieniła się w omawianym zakresie w 1998 r. w kierunku tworzenia szczegółowych regulacji wraz z uzyskaniem przez kilka Kościołów prawa procedowania formy wyznaniowej małżeństwa 583.

17 Ustawa z 25 II 1964 r. Kodeks rodzinny i opiekuńczy, Dz.U. z 2015 r., poz. 
świeckiego (dalej: forma wyznaniowa). ${ }^{18}$ Najobszerniejsze przepisy w tym zakresie przyjęto w Kościele Ewangelicko-Augsburskim w $\mathrm{RP}^{19}$ (dalej: KEA), w Kościele Ewangelicko-Metodystycznym w RP ${ }^{20}$ (dalej: KEM) i w Kościele Chrześcijan Baptystów w RP ${ }^{21}$ (dalej: KChB). Istotne znaczenie mają także stanowiska Kościołów o charakterze doktrynalnym, nie będące co prawda częścią przepisów prawa kościelnego, lecz mające podobną moc wiążącą. ${ }^{22}$

18 Prawo to uzyskały następujące Kościoły protestanckie: Kościół Ewangelicko-Augsburski w RP, Kościół Ewangelicko-Reformowany w RP, Kościół Ewangelicko-Metodystyczny w RP, Kościół Chrześcijan Baptystów w RP, Kościół Adwentystów Dnia Siódmego w RP, Kościół Zielonoświątkowy w RP. Wiele mniejszych Kościołów protestanckich pozbawionych jest prawa stosowania formy wyznaniowej. Postulaty prawodawcze w tym zakresie przynosi m.in. opracowanie: T. J. Z i e l i ń s k i, Nowy projekt przyznania prawa procedowania wyznaniowej formy matżeństwa cywilnego rejestrowym wspólnotom religijnym, w: M. R ó ż á s k i, J. K r z y w k o w s k a (red.), Rodzina w prawie. Księga pamiątkowa dedykowana ks. prof. dr. hab. Ryszardowi Sztychmilerowi z okazji 65. rocznicy urodzin i 30-lecia pracy naukowej, Olsztyn 2013, s. 215-226. Na temat formy wyznaniowej zob. A. M e z g l e w s k i, A. Tu n i a, Wyznaniowa forma małżeństwa cywilnego, Warszawa 2007, passim.

19 Omawiane przepisy pomieszczone są w szczególności w akcie: Pragmatyka stużbowa Kościoła Ewangelicko-Augsburskiego w Rzeczypospolitej Polskiej zatwierdzona na 4. Sesji Synodu X Kadencji ze zmianami dokonanymi do 7. Sesji Synodu XIII Kadencji; zob. http://bik.luteranie.pl/files/Prawo/2015-04-11PragmatykaSubowav. pp.pdf (dostęp: 30 V 2015) (dalej: PSKEA).

20 Prawo wewnętrzne Kościoła Ewangelicko-Metodystycznego (tekst jednolity), w: R. B r o ż y n i k, M. W i n i r c z y k - K o s s a k o w s k a (red.), Mniejszości wyznaniowe $w$ Polsce. Prawo wewnętrzne (statutowe). Wprowadzenie, zbiór statutów, opracowanie, Warszawa 2014, s. 43-56. Zawarcia małżeństwa na forum kościelnym dotyczą art. 72-76 tego aktu (dalej: PWKEM).

${ }^{21}$ Najistotniejszy jest w tym względzie akt: Przepisy prawne Kościoła Chrześcijan Baptystów w Rzeczypospolitej Polskiej oformie zawarcia matżeństwa chrześcijańskiego wywotujacej skutki w prawie polskim, w: Przepisy prawne Kościoła Chrześcijan Baptystów w Rzeczypospolitej Polskiej, Warszawa 2010, s. $91-93$ (dalej: $\mathrm{PPKChB).}$

22 Ich przykładem są przytaczane w dalszym wywodzie: uchwała Międzykonferencyjnego Zjazdu Delegatów Kościoła Chrześcijan Baptystów w RP z 3 V 1997 r. w sprawie małżeństwa i rodziny, Zasady wiary Kościoła Adwentystów Dnia Siódmego oraz Naczelnej Rady Kościoła Zielonoświatkowego w RP w sprawie 


\section{Pojęcie małżeństwa}

Zgodnie z tradycją ogólnochrześcijańską, uzasadnianą wypowiedziami zawartymi w Nowym Testamencie (m.in. Rdz 1:27n., 2:24; Mt 19:5-6, 5:31; Hbr 13:4) małżeństwo w protestantyzmie polskim pojmowane jest jako monogamiczny, dozgonny związek mężczyzny i kobiety, oparty na ustanowieniu Bożym. Nie uznaje się go za sakrament, tak jak to jest w Kościele katolickim i Kościołach prawosławnych. Wskazuje się bowiem, że nie ma ono materii właściwej sakramentom (jaką mają chrzest i Eucharystia) i nie zostało ustanowione przez Jezusa Chrystusa, choć przezeń w pełni usankcjonowane z zastrzeżeniem nierozerwalności. ${ }^{23}$

Opierając się na przepisach prawa i innych unormowaniach obowiązujących w Kościołach protestanckich w Polsce, można stwierdzić, że w ich ujęciu do istoty małżeństwa należy:

1. świadoma, dobrowolna i oparta na obustronnej zgodzie (umowie, przymierzu), publicznie zawarta, więź między jednym mężczyzną i jedną kobietą;

2. kultywowanie tej więzi (jedności) w celu wspólnej realizacji przez małżonków powołania chrześcijańskiego, w tym wzajemne dopełnienie duchowe i seksualne małżonków;

3. trwałość i nierozerwalność tej więzi określana w kategoriach „nieodwołalnego przymierza” (§ 108 PSKEA), ${ }^{24}$ „,trwałego

matżeństwa, rozwodu, powtórnego matżeństwa i planowania rodziny z listopada 1998.

23 Zob. Wyznanie ewangelicko-reformowane. Matżeństwo, w: Porównanie wyznań: rzymskokatolickiego, prawosławnego, ewangelicko-augsburskiego, ewangelicko-reformowanego, Warszawa 2002, s. 105; T. W o j a k, Ewangelik-katolik, Warszawa 1981, s. 95.

$24 \S 108$ PSKEA. Natomiast $§ 110$ tego aktu głosi: „Podstawowym prawem i obowiązkiem małżonków jest życie w miłości, wierności, jedności i nierozerwalności oraz tworzenie rodziny i wychowanie dzieci w wierze i wierności Kościołowi”; zob. M. H i n t z, Etyka ewangelicka i jej wymiar eklezjalny. Studium historyczno-systematyczne, Warszawa 2007, s. 390-394. Tam też znajduje się omówienie dokumentu Stanowisko Kościoła Ewangelicko-Augsburskiego wobec mał̇eństwa, uchwalonego przez Synod Kościoła w 2001 r. 
związku mężczyzny i kobiety”, ${ }^{25}$ „,związku na całe życie między mężczyzną i kobietą", ${ }^{26}$,nierozerwalny związek mężczyzny i kobiety". ${ }^{27}$ Stwierdzenie o nierozerwalności będzie jednak wymagało uściślenia w dalszym wywodzie.

Jak wynika z ugruntowanych w protestantyzmie zapatrywań w sprawie małżeństwa, warunkiem zaistnienia tego związku dwojga osób nie jest wola płodzenia i wychowywania dzieci. Pogląd ten znajduje wsparcie w wypowiedziach teologów protestanckich. ${ }^{28} \mathrm{Za}$ ważne uznawane będzie zatem także małżeństwo zawarte z zamiarem rezygnacji z prokreacji.

W Polsce nie istnieje dotąd Kościół protestancki uznający w swym porządku prawnym związki jednopłciowe. Nie podjęto także w tych wspólnotach próby objęcia tych związków pojęciem małżeństwa. Należy jednak pamiętać, że w skali globalnej, w tym także w Europie, wiele Kościołów tej tradycji akceptuje związki homoseksualne i przewiduje dla nich obrzęd błogosławieństwa religijnego. ${ }^{29}$

25 Punkt 1 uchwały Międzykonferencyjnego Zjazdu Delegatów Kościoła Chrześcijan Baptystów w RP z 3 V 1997 r. w sprawie małżeństwa i rodziny, Słowo Prawdy 1/1998, s. 27 (dalej: UKChB).

${ }^{26}$ Zasady wiary Kościoła Adwentystów Dnia Siódmego, w: Statut Kościoła Adwentystów Dnia Siódmego w Rzeczypospolitej Polskiej, Warszawa 1994, s. 88.

27 Stanowisko Naczelnej Rady Kościoła Zielonoświątkowego w RP w sprawie matzeństwa, rozwodu, powtórnego matżeństwa i planowania rodziny z listopada 1998, w: M. K a m i ń s k i, Kościół Zielonoświątkowy w Polsce w latach 1988-2008. Studium historyczno-ustrojowe, Warszawa 2012, s. 262-263.

28 W. B e n e d y k t o w i c z, Co powinniśmy czynić. Zarys ewangelickiej etyki teologicznej, Warszawa 1993, s. 151.

29 Odnotujmy, że w 2007 r. w Warszawie przedstawiciele Wolnego Kościoła Reformowanego dokonali publicznego aktu błogosławieństwa pary jednopłciowej. Akt ten z oczywistych względów nie pociągał za sobą skutków w prawie polskim. Wskazana wspólnota religijna nie posiada statusu związku wyznaniowego o uregulowanej sytuacji prawnej, nie jest też jasne, czy można ją uznać za podmiot o charakterze protestanckim, choć tak była niekiedy kojarzona; zob. T. J. Z i e 1 i ń s k i, Pojęcie religii, wyznania, związk wyznaniowego i kościoła w Konstytucji Rzeczypospolitej Polskiej, Prawo i Religia 1/2007, s. 48. 
Przesłanki zawarcia małżeństwa i przeszkody małżeńskie

Protestantyzm tradycyjnie przejawia wysoki szacunek dla państwa i jego prawa. Wynika to z przekonania, że państwo jako takie jest zgodne z zamysłem Bożym, zaś państwo i chrześcijaństwo nie są względem siebie konkurencyjne i choć należą do różnych porządków, łączy je zestaw spraw wspólnych i wspólnych celów. Współczesny protestantyzm nie ma roszczeń do zwierzchności nad władzą publiczną, zwykle przejawia chęć współpracy z nią, lecz zastrzega sobie prawo sprzeciwu wobec jej nieakceptowanych z perspektywy etyki chrześcijańskiej posunięć. ${ }^{30}$ Ta myśl wprowadzająca jest istotna przy prezentacji przesłanek zaistnienia małżeństwa i przeszkód małżeńskich, gdyż Kościoły protestanckie zwykle przyjmują państwowe wymagania $\mathrm{z}$ tego zakresu, uznając je za trafnie dobrane z perspektywy dobra ogólnospołecznego. Przy małżeństwie kościelnym dodają do nich własne kryteria o charakterze religijnym.

Przesłankami zawarcia małżeństwa w polskich Kościołach protestanckich są:

- różnica płci między dwiema osobami zawierającymi związek (nupturientami);

- bycie chrześcijaninem przez przynajmniej jednego z nupturientów;

- osiągnięcie przez nupturientów odpowiedniego wieku;

- wolny stan cywilny obu przyszłych małżonków;

- zgodna wola zawarcia małżeństwa przez nupturientów;

- publiczne złożenie oświadczeń woli zawarcia małżeństwa.

Za przeszkody (impedimenta) uznaje się zbyt bliskie pokrewieństwo, powinowactwo i upośledzenie psychiczne. Przeszkodą nie jest pełnienie urzędu kościelnego (posiadanie ordynacji), jako że reformacja zniosła obowiązek celibatu.

Powyższe ogólne warunki zawarcia małżeństwa podlegają obostrzeniu przy zawarciu na forum Kościołów protestanckich małżeństwa w rozumieniu prawa cywilnego, a tak się często dzieje w przypadku

30 W. B e ne d y k t o w i c z, Co powinniśmy czynić, s. 199-200. 
wyliczonych wcześniej Kościołów polskich mających prawo procedowania formy wyznaniowej. Wówczas obowiązują kryteria z Kodeksu rodzinnego i opiekuńczego. Oznacza to, że warunkiem zaistnienia małżeństwa zawieranego w formie wyznaniowej jest dodatkowo:

- osiągnięcie przez nupturientów określonego w prawie polskim wieku;

- brak istnienia między nupturientami więzi adopcyjnej;

- jednoczesna obecność i złożenie przez nupturientów zgodnych oświadczeń o wstąpieniu w związek małżeński przed właściwym duchownym; ${ }^{31}$

- sporządzenie przez kierownika Urzędu Stanu Cywilnego aktu małżeństwa.

Małżeństwo zawierane w Kościołach protestanckich jest określane jako małżeństwo chrześcijańskie, dlatego wśród wymogów jego zaistnienia wyliczono konieczność kwalifikowania się przynajmniej przez jednego z nupturientów jako chrześcijanina. Dla większości Kościołów wystarczającym dowodem tej kwalifikacji jest fakt bycia ochrzczonym. Jednakże istnieje duża grupa wspólnot protestanckich zwanych ewangelikalnymi, gdzie sam fakt bycia ochrzczonym może być uznany za niewystarczający jako znamię bycia chrześcijaninem. Przedstawiciel takiego Kościoła może domagać się dowodów na to, że nupturient jest zaangażowanym, „odrodzonym”, „, nowo narodzonym” chrześcijaninem. Jeśli przeprowadzający procedurę kwalifikacyjną reprezentant Kościoła stwierdzi, że tego rodzaju kryterium religijne nie jest spełnione, może dojść do odmowy przeprowadzenia aktu zawarcia małżeństwa na forum kościelnym. Kościoły omawianej tradycji zwykle wymagają, by oboje nupturienci wykazywali takie szczególne cechy pobożnościowe (,małżeństwo między wierzącymi”). ${ }^{32}$

$31 \S 121$ PSKEA dopuszcza expressis verbis zawarcie małżeństwa przez pełnomocnika.

32 Punkt 2 UKChB głosi, że Kościół ten: „Uznaje małżeństwo osoby wierzącej (odrodzonej) z niewierzącą (nieodrodzoną) za niezgodne z wolą Bożą (2Kor 6,14-15; 1Kor 7,39b.16; Ef 5,21-25; 1P 3,7; 1J 2,15), z wyjątkiem sytuacji opisanej 


\section{Forma zawarcia małżeństwa}

W sześciu polskich Kościołach protestanckich, które mają prawo procedowania wyznaniowej formy małżeństwa cywilnego, ceremonia kościelna zawarcia związku ze skutkami cywilnymi obok elementów wymaganych przez Kodeks rodzinny i opiekuńczy zawiera czynniki o charakterze religijnym. Należą do nich m.in. ślubowanie wierności Bogu i religijne zobowiązanie wierności przyszłemu współmałżonkowi, czytanie perykop z Pisma Świętego, modlitwa i stosowne pouczenie religijne. Należy przy tym pamiętać, że obok stosowania formy wyznaniowej małżeństwa cywilnego we wszystkich tych Kościołach honorowane są małżeństwa zawarte w formie czysto świeckiej ${ }^{33}$ oraz zawiera się małżeństwa ważne tylko na forum kościelnym (bez skutków cywilnych). Kościoły zwykle minimalizują liczbę ślubów bez skutków cywilnych. Praktykuje się też błogosławienie par, które uprzednio zawarły związek cywilny. ${ }^{34}$

Dwa Kościoły protestanckie procedujące na swoim forum zawarcie małżeństwa cywilnego określiły w przepisach prawa wewnętrznego rotę ślubowania małżeńskiego, która stanowi obowiązkowy element formy wyznaniowej. Są to $\mathrm{KEM}^{35}$ i KChB. ${ }^{36}$

w 1Kor 7,12-14". Trudno jednak przyjąć, że małżeństwo takie uważa się w KChB za nieważne. W stanowisku NRKZ nie pozostawia się w tym względzie wątpliwości: „3. Zawieranie związku małżeńskiego przez osobę wierzącą z niewierzącą - mimo ważności tego małżeństwa - uważa się za niezgodne z wolą Bożą (2Kor 6, 14-16)".

33 Wyznanie ewangelicko-reformowane. Małżeństwo, s. 105.

34 Zob. np. art. 76 PWKEM, który brzmi: „W szczególnych przypadkach dopuszczalne jest zawarcie związku małżeńskiego przed urzędnikiem Urzędu Stanu Cywilnego, a następnie pobłogosławienie go przez duchownego".

35 „Uroczystą formułą zawarcia związku małżeńskiego są wypowiedziane przez każdego z nupturientów następujące słowa formuły ślubnej: Ja (imię kobiety lub mężczyzny) biorę sobie ciebie za męża/żonę i ślubuję nie opuścić cię ani w dobrym ani w złym, ani w bogactwie ani w ubóstwie, ani w zdrowiu ani w chorobie, ale przyrzekam kochać cię i szanować aż do czasu, kiedy Bogu Najwyższemu upodoba się rozłączyć nas i aż dotąd ślubuję ci wierność" (art. 74 ust. 2 PWKEM).

36 „Oświadczenia (...) składa się w sposób następujący. Na pierwsze pytanie duchownego wyrażone w słowach: «N. (imię narzeczonego) i N. (imię narzeczonej), 
Kościoły protestanckie nie mające prawa procedowania formy wyznaniowej małżeństwa świeckiego zwykle wymagają odbycia ślubowania religijnego przed duchownym, co oczywiście nie pociąga za sobą skutków cywilnych.

Świadkami kwalifikowanymi formy wyznaniowej są w Kościołach protestanckich duchowni wskazani w obwieszczeniu Ministra Spraw Wewnętrznych z 5 lutego 2015 r. w sprawie ogłoszenia wykazu stanowisk, których zajmowanie upoważnia do przyjmowania oświadczeń o wstąpieniu w związek małżeński oraz sporządzania zaświadczeń stanowiących podstawę sporządzania aktu małżeństwa zawartego w sposób określony w art. 1 § 2 i 3 Kodeksu rodzinnego i opiekuńczego. ${ }^{37} \mathrm{~W}$ pozostałych Kościołach zawarciu małżeństwa chrześcijańskiego również asystują duchowni.

\section{Unieważnienie małżeństwa}

Procedura stwierdzenia nieważności małżeństwa jest w protestantyzmie na forum kościelnym niebywałą rzadkością. Dotyczy to także Kościołów w Polsce. Wydaje się, że jest to wynikiem niesakramentalnego charakteru aktu zawarcia małżeństwa i uznawania doniosłości przede wszystkim węzła cywilnego. Jeżeli zatem zachodzi potrzeba

\footnotetext{
czy chcecie dobrowolnie i bez żadnego przymusu zawrzeć chrześcijański związek małżeński?», narzeczony odpowiada «Tak, chcę» oraz narzeczona odpowiada «Tak, chcę». Na drugie pytanie duchownego wyrażone w słowach: «N. (imię narzeczonego) i N. (imię narzeczonej), czy chcecie, aby związek małżeński obecnie zawierany wywołał skutki przewidziane w prawie Rzeczpospolitej Polskiej?», narzeczony odpowiada «Tak, chcę» oraz narzeczona odpowiada «Tak, chcę». Dalej narzeczony powtarza za duchownym słowa: «Ja, N. (imię narzeczonego), biorę Ciebie N. (imię narzeczonej) za żonę i ślubuję Ci miłość, wierność i uczciwość małżeńską oraz że Cię nie opuszczę aż do śmierci. Tak mi dopomóż Panie Boże Wszechmogący, w Trójcy jedyny». Następnie narzeczona powtarza za duchownym: «Ja, N. (imię narzeczonej), biorę Ciebie N. (imię narzeczonego) za męża i ślubuję Ci miłość, wierność i uczciwość małżeńską oraz że Cię nie opuszczę aż do śmierci. Tak mi dopomóż Panie Boże Wszechmogący, w Trójcy jedyny»” (art. 5 ust. 1 PPKChB).

37 M.P. z 2015 r., poz. 230.
} 
ustalenia nieważności związku to dokonuje się ona tylko na forum cywilnym. ${ }^{38}$

\section{Rozwód i ponowne małżeństwo}

Rozwód małżeński stanowi w Kościołach protestanckich złożone zagadnienie. Już zaznaczaliśmy, że wspólnoty te głoszą nierozerwalność małżeństwa. Jednakże analiza przepisów prawa i innych norm obowiązujących $\mathrm{w}$ tych podmiotach, tudzież praktyka $\mathrm{z}$ omawianego zakresu dowodzi, że rozwody są tam w pewnych przypadkach sankcjonowane post factum. Kościoły zastrzegają przy tym, że nie przeprowadzają postępowania rozwodowego, nie wydają wyroków rozwodowych. W § 145 PSKEA czytamy: „Kościół Ewangelicko-Augsburski w RP stoi na biblijnym stanowisku nierozerwalności małżeństwa. Tam jednak, gdzie małżeństwo uległo rozpadowi i zostało rozwiedzione wyrokiem Sądu, przyjmuje do wiadomości istniejący stan rzeczy jako wynik ludzkiego grzechu i zatwardziałości serc. Kościół nie przeprowadza postępowania rozwodowego". Jednakże wobec faktu zaistnienia rozwodu wiele Kościołów protestanckich w pewnej postaci przewiduje procedurę wyrażenia zgody na ponowny związek małżeński osoby rozwiedzionej.

Zgodnie z zasadą postrzegania Pisma Świętego w protestantyzmie jako nadrzędnego autorytetu w sprawach wiary i praktyki chrześcijańskiej, wiodącą podstawą unormowań w omawianych kwestiach są perykopy biblijne zawierające wypowiedzi Chrystusa i Jego uczniów dotyczące małżeństwa. Mimo powoływania passusów biblijnych między Kościołami protestanckimi występują różnice w zakresie

$38 \mathrm{~W}$ jednej z teologicznych prezentacji doktryny i praktyki Kościoła Ewangelicko-Augsburskiego w Polsce znalazła się fraza następująca: „Unieważnienia małżeństwa dokonać może tylko biskup lub komisja Synodu do spraw małżeństwa. Jest to jednak sytuacja wyjątkowa i bardzo smutna"; Wyznanie ewangelicko-augsburskie. Matżeństwo w: Porównanie wyznań: rzymskokatolickiego, prawosławnego, ewangelicko-augsburskiego, ewangelicko-reformowanego, s. 97-98. Wydaje się, że pojęcie ,unieważnienie małżeństwa” zastosowane zostało tutaj w sensie innym niż powszechnie przyjęte. Autorzy najprawdopodobniej mieli na myśli rozwód. 
ich aplikacji. Zwykle dopuszcza się trzy podstawy uznania rozwodu cywilnego i dopuszczenia do ponownego związku małżeńskiego na forum kościelnym. Są to: złośliwe porzucenie (Mt 5,32); cudzołóstwo (Mt 19,9); tzw. przywilej Pawłowy (przywilej wiary) (1Kor 7,11-15). ${ }^{39}$

Zazwyczaj osoby, których małżeństwo zostało rozwiązane przez rozwód wyrokiem sądu cywilnego starają się o przyjęcie przez Kościół do wiadomości tegoż rozwodu i wydanie zezwolenia na nowy ślub kościelny. ${ }^{40}$ Dowody przedstawione w postępowaniu rozwodowym przeprowadzanym przez sąd cywilny mogą służyć do wykazania przed kompetentną władzą kościelną (organem kościelnym), że zaszła któraś z biblijnych przesłanek do uregulowania ich sytuacji w Kościele.

Poszczególne Kościoły w różny sposób podchodzą do wniosków o zgodę na ponowne małżeństwo. Można wyróżnić trzy zasadnicze modele postępowania $\mathrm{w}$ tym zakresie.

Model 1 - c e n tra li s t y c z n y. W Kościele istnieje jeden organ centralny upoważniony do wydawania zezwolenia na ponowny związek małżeński na forum kościelnym. Takie rozwiązanie jest przyjęte w KEA. Organem jest biskup Kościoła, który wydaje decyzję, opierając się na wniosku osoby rozwiedzionej zaopiniowanym przez właściwego proboszcza (§ 147 PSKEA). W okresie międzywojennym sprawy takie prowadziło ciało kolegialne: konsystorz Kościoła. ${ }^{41}$

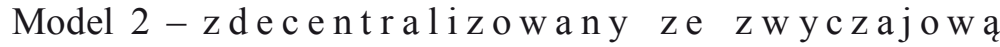
kompetencją do orzekania. Nie istnieje centralny organ orzekający. Nie ma przepisów w tej sprawie, ale panuje powszechnie akceptowany zwyczaj załatwiania tych spraw przez lokalny organ kościelny. Takie rozwiązanie jest przyjęte w KER i KZ. Orzeka

39 Zob. W. B e n e dy k tow i c z, Co powinniśmy czynić, s. 152-153; pkt 3 UKChB; pkt 5 stanowiska NRKZ.

${ }^{40}$ W niektórych Kościołach protestanckich, zwłaszcza o profilu ewangelikalnym, osoba rozwiedziona nie stara się o ponowny ślub kościelny, lecz o faktyczną akceptację nowego małżeństwa cywilnego. Akceptacja ta zwykle polega na niezastosowaniu do rozwodnika (rozwodników) sankcji dyscyplinarnych i zezwoleniu mu (im) na pełny udział we wszystkich praktykach religijnych, w tym i na pełnienie funkcji kościelnych (wyjątek zwykle dotyczy pełnienia godności duchownego).

${ }_{41}$ W. B e n e d y k t o w i c z, Co powinniśmy czynić, s. 154. 
proboszcz (pastor) parafii. Jednoosobowo wydaje zgodę na zawarcie nowego związku małżeńskiego na forum kościelnym i osobiście udziela ślubu. ${ }^{42}$

Model $3-z d e c e n t r a l i z o w a n y ~ b e z$ powszechnie akceptowanej kompetencji do orzekania. Nie istnieje centralny organ orzekający. Nie ma przepisów w tej sprawie. Taki model realizowany jest w KChB. Rada Zboru (organ kolegialny) rozpatruje wniosek osoby rozwiedzionej o zgodę na zawarcie kolejnego małżeństwa, względnie o niestosowanie sankcji dyscyplinarnej z tytułu zawarcia ponownego związku cywilnego. Czasami sprawa trafia na forum całej gminy kościelnej (zboru), gdzie przypadek roztrząsany jest gremialnie. Niekiedy zapadają decyzje przychylne. Niektóre zbory jednak stanowczo odmawiają rozpatrywania takich spraw i ponowne małżeństwo nie jest dopuszczane pod żadnym pozorem. W konsekwencji, w skali całego związku wyznaniowego istnieje brak jednolitości w załatwianiu wniosków o zgodę na zawarcie ponownego małżeństwa, względnie usankcjonowanie zawarcia ponownego małżeństwa cywilnego. ${ }^{43}$

$\mathrm{Na}$ koniec rozważań dotyczących zagadnień rozwodu i zawarcia przez osoby rozwiedzione ponownych związków trzeba nadmienić, że w przypadku duchownych, którzy znaleźli się w takich okolicznościach życiowych, zwykle stosuje się surowsze wymagania, w tym i sankcje dyscyplinarne. W Kościele Zielonoświątkowym obowiązuje stanowisko wyrażone w słowach: „Osoby duchowne nie mogą być rozwiedzione (1Tm 3, 2.11-12; Tt 1, 5-7)"'.44 W Kościele Ewangelicko-Augsburskim obowiązuje natomiast bardziej liberalna norma w brzmieniu: „W przypadku rozwodu duchownego Biskup Kościoła i Rzecznik Dyscyplinarny decyduje, czy może on pozostawać na

42 Pkt 6 Stanowiska NRKZ.

43 J. B u r n e 11, Rozwód i powtórne matżeństwo w Kościołach ewangelikalnych, w: S. S m ol a r z, S. Tor b u s, W. K ow a lew s k i (red.), Ewangelikalizm polski wobec wyzwań współczesności, Wrocław 2013, s. 219.

${ }_{44}$ Pkt 7 Stanowiska NRKZ. 
dotychczasowym stanowisku względnie nadal piastować urząd duchowny w Kościele". ${ }^{5}$

$* * *$

Małżeństwo w polskich Kościołach protestanckich jest postrzegane jako naturalny, podstawowy stan społeczny mający mandat Boży, zasługujący na popieranie przez chrześcijan i ochronę z ich strony. Jest to monogamiczny, heteroseksualny i trwały (dozgonny) związek dwóch osób, z których przynajmniej jedna jest wyznawcą Chrystusa. Do istoty małżeństwa nie należy wola prokreacji. Zawarcie węzła małżeńskiego $\mathrm{w}$ formie religijnej jest uznawane za praktykę pożądaną, lecz dopuszczalne są odstępstwa od niej na rzecz innej formy publicznej. Prawo zawierania związków małżeńskich mają także duchowni, podlegający wszakże w tym zakresie większym rygorom niż pozostali chrześcijanie.

Większość Kościołów protestanckich wobec orzeczenia przez sąd cywilny rozwodu zezwala wiernym, nie ponoszącym winy za rozpad poprzedniego związku, na zawarcie kolejnego małżeństwa. Stosowane są tu różne modele postępowania. Część z nich (modele zdecentralizowane) w oczach obserwatorów uchodzi za sprzyjające niejednolitości orzecznictwa małżeńskiego.

Tadeusz J. ZIELIŃSKI

$45 \S 151$ ust. 3 PSKEA. 